\title{
Triiodothyronine administration reverses vitamin A deficiency-related hypo-expression of retinoic acid and triiodothyronine nuclear receptors and of neurogranin in rat brain
}

\author{
Marianne Husson, Valérie Enderlin, Serge Alfos, Catherine Féart, Paul Higueret and \\ Véronique Pallet* \\ Unité de Nutrition et Signalisation Cellulaire (E.A. MENRT; USC INRA) ISTAB, Université Bordeaux 1, \\ Avenue des Facultés, 33405 Talence cedex, France
}

(Received 7 May 2002 - Revised 23 December 2002 - Accepted 10 February 2003)

\begin{abstract}
Recent studies have revealed that retinoids play an important role in the adult central nervous system and cognitive functions. Previous investigations in mice have shown that vitamin A deficiency (VAD) generates a hypo-expression of retinoic acid (RA, the active metabolite of vitamin A) receptors and of neurogranin (RC3, a neuronal protein involved in synaptic plasticity) and a concomitant selective behavioural impairment. Knowing that RC3 is both a triiodothyronine $\left(\mathrm{T}_{3}\right)$ and a RA target gene, and in consideration of the relationships between the signalling pathways of retinoids and thyroid hormones, the involvement of $T_{3}$ on RA signalling functionality in VAD was investigated. Thus, the effects of vitamin A depletion and subsequent administration with RA and/or $\mathrm{T}_{3}$ on the expression of RA nuclear receptors (RAR, RXR), $T_{3}$ nuclear receptor (TR) and on RC3 in the brain were examined. Rats fed a vitamin A-deficient diet for 10 weeks exhibited a decreased expression of RAR, RXR and TR mRNA and of RC3 mRNA and proteins. RA administration to these vitamin A-deficient rats reversed only the RA hypo-signalling in the brain. Interestingly, $T_{3}$ is able to restore its own brain signalling simultaneously with that of vitamin A and the hypo-expression of RC3. These results obtained in vivo revealed that one of the consequences of VAD is a dysfunction in the thyroid signalling pathway in the brain. This seems of crucial importance since the down regulation of RC3 observed in the depleted rats was corrected only by $\mathrm{T}_{3}$.
\end{abstract}

Vitamin A deficiency: Retinoic acid nuclear receptors: Triiodothyronine nuclear receptors: Brain: Neurogranin

Vitamin A and its derivatives (the retinoids) participate in many physiological processes including vision and reproduction (Sporn et al. 1994), and exert a wide variety of profound effects on vertebrate development, cellular differentiation and homeostasis (Chambon, 1996). In addition to the well-known and important role of retinoids and particularly retinoic acid (RA, the active metabolite of vitamin $\mathrm{A}$ ) during the normal development of the central nervous system (Maden et al. 1998; Környei et al. 1999; Malik et al. 2000), various data suggest that retinoids play a significant role in the adult central nervous system. Initial investigations have shown that the adult brain: (i) is a retinoid-metabolizing tissue (McCaffery \& Dräger, 1994; Connor \& Sidell, 1997); (ii) contains cellular RA and retinol-binding protein as well as a high level of nuclear RA receptors (Krezel et al. 1999; Zetterström et al. 1999). The RA receptors, RAR (whose ligands are the all-transRA and 9-cis-RA isomers) and RXR (whose ligand is the 9-cis-RA isomer), are DNA-binding proteins which, upon activation by specific retinoid ligands, induce gene transcription by interacting with distinct promoter sequences in the target genes (Kastner et al. 1995). Therefore, changes at the retinoid level are capable of producing alterations in several neuronal target proteins and consequently may affect physiological process maintenance in the mature brain (Malik et al. 2000). Indeed, knockout mice for RAR $\beta$ and RAR $\beta-\operatorname{RXR} \gamma$ display an alteration of long-term potentiation (the most widely studied form of synaptic plasticity, thought to underlie memory formation), as well as substantial performance deficits in a hippocampal-dependent spatial learning task (Chiang et al. 1998). A similar conclusion can also be drawn from recent studies using mice or rats receiving a postnatally induced vitamin A-deficient diet (Misner et al. 2001; Cocco et al. 2002). Moreover, our recent studies have shown that a moderate down regulation of retinoidmediated transcription events naturally occurs with senescence (Enderlin et al. 1997). An administration of RA

Abbreviations: GAPDH, glyceraldehyde 3-phosphate dehydrogenase; PCR, polymerase chain reaction; RA, retinoic acid; RAR, retinoic acid receptor; $\mathrm{RC} 3$, neurogranin; RXR, retinoid X receptor; $\mathrm{T}_{3}$, triiodothyronine; TR, triiodothyronine nuclear receptor; tTG, tissue-type transglutaminase; VAD, vitamin A deficiency.

* Corresponding author: Dr Véronique Pallet, fax +33 5568427 76, email v.pallet@istab.u-bordeaux1.fr 
restores to pre-senescent levels the age-related decrease in brain expression of its own receptors and of neurogranin (RC3), a specific associated target gene (Iñiguez et al. 1994; Enderlin et al. 1997) involved in synaptic plasticity (Gerendasy \& Sutcliffe, 1997; Pak et al. 2000), and concomitantly alleviates both the relational memory and hippocampal long-term potentiation seen in aged mice (Etchamendy et al. 2001). Together these data suggest that a fine regulation of retinoid-mediated gene expression is fundamentally important for optimal brain functioning.

A previous study, obtained in our laboratory using a murine model, has evidenced that vitamin A deficiency (VAD) leads to a reduced expression of brain retinoid nuclear receptors and that of RC3 as well as selective behavioural impairment (Etchamendy et al. 2000). Surprisingly, RA administration to these animals failed to fully normalize the expression of the genes studied and had no effect on the associated cognitive deficit. It is well known that the activity field and signalling pathway of retinoids and thyroid hormones, whose active metabolite is triiodothyronine $\left(\mathrm{T}_{3}\right.$ ), are in close relationship (Schräder \& Carlberg, 1994; Chin \& Yen, 1997). Moreover, alterations of thyroid hormone metabolism and functionality associated with VAD have been described (Ingenbleek \& De Visscher, 1979; Okamura et al. 1981; Higueret \& Garcin, 1984). Finally, RC3 is not only under the influence of retinoids (Iñiguez et al. 1994), but is regulated by thyroid hormone too (Guadaño-Ferraz et al. 1997; Morte et al. 1997; Martinez de Arrieta et al. 1999).

Thus, in the present work, the question arose regarding the possible implication of thyroid disorders in RA impairment in restoring neurological alterations to normal. Therefore, an examination was made first of the consequences of a vitamin A-deprived diet on $\mathrm{T}_{3}$ and $\mathrm{RA}$ nuclear receptors expression (TR, RAR and RXR, respectively), and on two of their target genes, RC3, and tissue-type transglutaminase (tTG); the tTG is a protein whose expression is highly regulated by RAR (Chiocca et al. 1989) and is considered as a biological marker of early VAD (Savouré et al. 1996). Second, the effect of administration of RA and/or $T_{3}$ in vitamin A-deficient animals was studied.

\section{Materials and methods}

\section{Experimental design}

The study was conducted in accordance with the European Communities Council Directives (861609/EEC). All the experiments conformed to the Guidelines on the Handling and Training of Laboratory Animals. The experimental design of postnatal VAD was according to AudouinChevallier et al. (1993). Weaning male Wistar rats were purchased from Harlan (Gannat, France). They were maintained in a room with a constant airflow system, controlled temperature $\left(21-23^{\circ} \mathrm{C}\right)$ and a $12 \mathrm{~h}$ light-dark cycle. The rats were allowed to have ad libitum access to food and tap water and were divided into two experimental groups: vitamin A-deficient (forty-eight animals); control (twelve animals). The vitamin A-deficient diet was composed as indicated in Table 1; the control diet was the same plus vitamin A $(1515 \cdot 15 \mathrm{RE} / \mathrm{kg}$ diet $)$.
Table 1. Composition of the diet*

\begin{tabular}{lc}
\hline Ingredients & Amount $(\mathrm{g} / \mathrm{kg})$ \\
\hline Vitamin-free caseint & 180 \\
Sucrose & 305 \\
Peanut oil & 25 \\
Rapeseed oil & 25 \\
Cellulose & 20 \\
Maize starch & 400 \\
Mineral mixture $\ddagger$ & 35 \\
Vitamin mixture§ & 10
\end{tabular}

*Vitamin A-sufficient diet according to Audouin-Chevallier et al. (1993). Chow was stored in sealed bags at $20^{\circ} \mathrm{C}$ and conserved after opening for a maximum of 1 week at $4^{\circ} \mathrm{C}$.

† Vitamin-free casein from Touzard et Matignon, France.

¥ Mineral mixture no. 102 from INRA (Jouy en Josas, France) consisted of the following ( $\mathrm{g} / \mathrm{kg}$ chow): calcium phosphate dibasic, 500; sodium chloride, 74; potassium monohydrate citrate, 220; magnesium sulfate, 52 ; magnesium oxide, 24; manganous carbonate (430-480 g Mn/kg manganous carbonate), 3.5 ; iron citrate (160-170 g Fe/kg iron citrate), 6; zinc carbonate $(700 \mathrm{~g}$ zinc oxide/kg zinc carbonate), 1.6; copper carbonate (530-550 g Cu/kg copper carbonate), 0.3; potassium iodate, 0.01; sodium selenite $(456.5 \mathrm{~g} \mathrm{Se} / \mathrm{kg}$ sodium selenite), 0.022 ; potassium and chromium sulfate, 0.55 ; sucrose to make up to $1 \mathrm{~kg}$.

\$Vitamin Diet Fortification Mixture without vitamin A no. 102 from INRA (Jouy en Josas, France) consisted of the following ( $\mathrm{g} / \mathrm{kg}$ chow): thiamine $\mathrm{HCl}, 0.6$; riboflavin, 0.6; pyridoxine $\mathrm{HCl}, 3.0$; D-calcium panthotenate, 1.6; folic acid, 0.2; D-biotin, 0.02; cyanocobalamin, 0.01; cholecalciferol, 0.00625; all-rac- $\alpha$-tocopherol, 5; menadione, 0.05; ascorbic acid, 0.45; sucrose to make up to $1 \mathrm{~kg}$.

Animals were fed these diets for 10 weeks. No difference between the different groups of rats was observed concerning the amount of food intake. At the time when the growth of the deficient animals slowed down, before weight reached a plateau and before the onset of apparent diseases was noted (these characteristics have previously been noted in the laboratory; Higueret \& Garcin, 1982), some of depleted rats were injected daily $(150 \mu \mathrm{g} / \mathrm{kg}$ body weight) for $4 \mathrm{~d}$ with RA (all-trans-RA, Sigma St Quentin Fallavier, France, no. R2625; ) and/or $\mathrm{T}_{3}$ (Sigma no. T2752) or vehicle only. Twelve rats were used for each treatment. Control rats were administrated with vehicle. The RA and $T_{3}$ were dissolved in a mixture (vehicle) containing polyethyleneglycol- $\mathrm{NaCl}-$ ethanol (70:20:10, by vol.). Rats were killed by decapitation. The brain and the liver were rapidly removed, weighed and stored at $-80^{\circ} \mathrm{C}$ for subsequent analysis. Brains and livers of the different groups exhibited no weight differences.

\section{Quantification of $m R N A$}

Extraction of RNA was performed according to Chomczynski \& Sacchi (1987).

\section{Reverse transcription}

The cDNA was synthesized with Superscript II reverse transcriptase (Invitrogen, Cergy Pontoise, France) according to the protocol recommended by the manufacturer with minor modifications. Briefly, $1 \mu \mathrm{g}$ total RNA was incubated at $70^{\circ} \mathrm{C}$ for $10 \mathrm{~min}$ and then placed on ice before addition of reverse transcriptase reaction reagents with a specific reverse primer $(120 \mathrm{ng}$ ) in a final volume of $20 \mu \mathrm{l}$. The reverse transcriptase reaction was performed 
at $42^{\circ} \mathrm{C}$ for $60 \mathrm{~min}$. Parallel reactions for each RNA sample were run in the absence of reverse transcriptase to assess the degree of any contaminating genomic DNA.

\section{Analysis of gene expression using real-time polymerase chain reaction}

The polymerase chain reaction (PCR) was carried out using a LightCycler system (Roche Diagnostics, Mannheim, Germany), which combines the processes of amplification and detection (by fluorescence) of a PCR product, thereby enabling on-line and real-time detection. To detect targetgene amplification products, LightCycler DNA Master SYBR Green I was used according to the manufacturer's instructions. The PCR reactions were performed in microcapillary tubes in a final volume of $20 \mu$ l containing $1 \mathrm{X}$

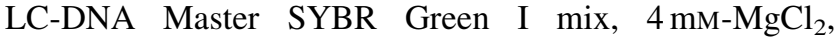
$0.5 \mu \mathrm{M}$ of each primer and $2 \mu \mathrm{l}$ cDNA. The amplification conditions were $95^{\circ} \mathrm{C}$ for $10 \mathrm{~min}$ to activate the polymerase, followed by forty cycles of denaturation at $95^{\circ} \mathrm{C}$ for $6 \mathrm{~s}$, annealing at about $60^{\circ} \mathrm{C}$ (according to the gene studied) for $6 \mathrm{~s}$, and elongation at $72^{\circ} \mathrm{C}$ for $10 \mathrm{~s}$. After each elongation phase the fluorescence of SYBR Green I (a double-stranded DNA-binding dye) was measured and increasing amounts of PCR products were monitored from cycle to cycle. The forward and reverse primer sequences are shown in Table 2. For each primer pair used, melting curve analysis showed a single melting peak after amplification, indicating a specific product.

Quantification data were analysed using the LightCycler analysis software, version 3.5 (Roche Diagnostics, Mannheim, Germany). In this analysis, the background fluorescence was removed by setting a noise band. The log-linear portion of the standard amplification curve was identified and the crossing point was the intersection of the best-fit line through the log-linear region and the noise band. The standard curve was a plot of the crossing point $v$. the amount of initial cDNA used for amplification. Standard curves were generated from 4-fold serial dilutions of target and housekeeping (glyceraldehyde 3-phosphate dehydrogenase; GAPDH) cDNA preparation. The relationship between the crossing point and the initial amount of cDNA was found to be linear. The correlation coefficient $(r)$ was 1 and PCR amplification efficiencies of the target and the housekeeping gene were similar and close to $100 \%$. These standard curves were used to estimate the concentration of both the target and the GAPDH gene in each sample. Then, the results were normalized by the ratio of the relative concentration of target to that of GAPDH in the same sample.

\section{Western blot analysis}

Western blot analysis was performed according to the procedure of Watson et al. (1990) with minor modifications. Brain tissue from the control rats, the deficient rats and deficient rats treated with RA and/or $\mathrm{T}_{3}$ was homogenized in $0 \cdot 16 \mathrm{M}-\mathrm{NaCl}, 11 \mathrm{~mm}$-sodium phosphate, $\mathrm{pH} 7.4$. Just before homogenisation, $1.5 \mu \mathrm{m}$-PMSF was added. The homogenate was then centrifuged at $10000 \mathrm{~g}$. A sample of the supernatant fraction was removed for protein assay. Then SDS and dithiothreitol were added to a final concentration of $1 \%(\mathrm{w} / \mathrm{v})$ and $50 \mathrm{~mm}$, respectively. Proteins were separated electrophoretically by size in a $12 \%(\mathrm{w} / \mathrm{v})$ denaturing SDS-polyacrylamide gel and transferred to a nitrocellulose membrane by electroblotting. The membrane was pre-blocked with $5 \%$ non-fat milk in PBS-Tween 20 buffer $\quad(145 \mathrm{mM}-\mathrm{NaCl}, \quad 1.5 \mathrm{~mm}-$ monohydrate sodium phosphate, $8 \mathrm{~mm}$-anhydrous sodium phosphate and $1 \%$ Tween 20), incubated overnight with polyclonal rabbit anti-neurogranin antibodies (diluted 1:3000, Affinity Research Product, Le Perray en Yvelines, France, no. NA $1300)$ or monoclonal mouse anti- $\beta$-actin antibodies (1:8000; Sigma no. A-5441), and washed briefly with PBS-Tween 20 buffer. Immunoreactive polypeptide bands were visualized enzymically in a secondary antibody reaction using alkaline phosphatase-conjugated anti-rabbit (Sigma no. A-0545) or anti-mouse immunoglobulin G (Amersham, Orsay, France, no. Na 93; ). The staining intensity of protein bands was determined using an image analyser (Bio 1D; Vilbert Lourmat, Marne La Vallée, France). The relative levels of RC3 and $\beta$-actin proteins were determined as a percentage of the RC3 and $\beta$-actin in control rats.

Table 2. Primers used for LightCycler ${ }^{\mathrm{TM}}$ real-time polymerase chain reaction $(P C R)$ with sequences forward $(F)$ and reverse $(R)$ primers, and size of amplicon

\begin{tabular}{|c|c|c|c|c|}
\hline PCR primer pair & Ref. & Sequence & Position & Product length (bp) \\
\hline \multirow[t]{2}{*}{ GAPDH } & Sabath et al. $(1990)^{*}$ & F: 5-GAACATCATCCCTGCATCCA-3 & $1455-1474$ & \\
\hline & & R: 5-CCAGTGAGCTTCCCGTTCA-3 & $1532-1514$ & 78 \\
\hline \multirow[t]{2}{*}{ RAR $\beta$} & Zelent et al. (1989)† & F: 5-CAGCTGGGTAAATACACCACGAA-3 & $786-808$ & \\
\hline & & R: 5-GGGGTATACCTGGTACAAATTCTGA-3 & $1012-988$ & 227 \\
\hline \multirow{2}{*}{$\mathrm{RXR} \beta / \gamma$} & Mangelsdorf et al. (1992) $\ddagger$ & F: 5-AGGCAGGTTTGCCAAGCTTCTG-3 & $1361-1382$ & \\
\hline & & R: 5-GGAGTGTCTCCAATGAGCTTGA-3 & $1462-1441$ & 102 \\
\hline \multirow[t]{2}{*}{$\mathrm{TR} \alpha / \beta$} & Murray et al. (1988)§ & F: 5-TCCTGATGAAGGTGACGGACCTGC-3 & $1247-1270$ & \\
\hline & & R: 5-TCAAAGACTTCCAAGAAGAGAGGC-3 & $1364-1341$ & 118 \\
\hline \multirow[t]{2}{*}{$\mathrm{RC} 3$} & Watson et al. (1990)\| & F: 5-GCTCCAAGCCAGACGACGATATTC-3 & $29-53$ & \\
\hline & & R: 5-CTTCTTCTATTTCTCGCСTCTCAC-3 & $152-128$ & 127 \\
\hline
\end{tabular}

GAPDH, glyceraldehyde 3-phosphate dehydrogenase; RAR, retinoic acid receptor; RXR, retinoid X receptor; TR, triiodothyronine receptor; RC, neurogranin. * From murine GAPDH cDNA.

†From murine RAR $\beta$ CDNA.

$\ddagger$ From murine RXR $\beta$ cDNA

$\S$ From rat TR $\beta$ CDNA.

|| From rodent $\mathrm{RC} 3 \mathrm{cDNA}$. 


\section{Assay for tissue transglutaminase activity}

Brain homogenates for the tTG assay were prepared as previously described by Alfos et al. (1996). Tissue transglutaminase-specific activity was measured by detecting the incorporation of $\left[{ }^{3} \mathrm{H}\right]$ putrescine into $\mathrm{N}, \mathrm{N}^{\prime}$-dimethylcasein.

\section{Serum retinol assay}

Serum retinol was assayed by HPLC according to the method of Leclercq \& Bourgeay-Causse (1981).

\section{Liver retinol and retinyl palmitate assay}

Liver retinol and retinyl palmitate were assayed by HPLC according to the method of Savouré et al. (1996).

\section{Proteins}

Proteins were determined according to Bradford (1976) using a Bio-Rad protein assay (Bio-Rad Laboratories, Munich, Germany).

\section{Statistical analysis}

Values are given as means and standard errors of the mean. The statistical significance of differences between means was calculated by ANOVA followed by Student's $t$ test $(P<0.05)$ using Minitab Statistical Software (State College, PA, USA).

\section{Results}

\section{Growth curve}

Fig. 1 shows the effects of vitamin A-deprived diet consumption during 10 weeks in vitamin A-deficient and control rats. After 10 weeks the body weight of

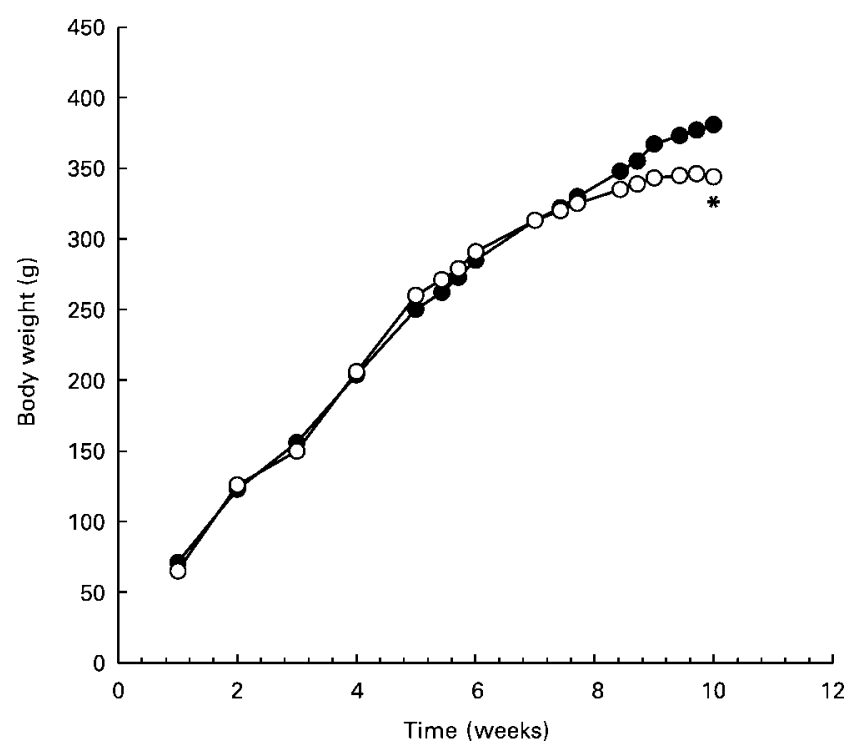

Fig. 1. Effect of 10 weeks consumption of vitamin A-depleted diet on body weight. Each point is the mean for twelve rats. (-0-), control rats; (-○-), depeleted rats. *Mean value was significantly different from that of the control animals. vitamin A-deficient rats was significantly lower than that of control. The average difference between body weights of the two groups after 10 weeks was $36 \cdot 35 \mathrm{~g}$.

\section{Effect of vitamin A deficiency on liver retinol and retinyl palmitate}

The liver retinyl palmitate and retinol concentrations were measured in control and depleted rats. Retinyl palmitate appeared nearly undetectable in vitamin A-deficient rat liver $(<1 v .355$ (SEM 29) nmoles/g liver in control rats) after 10 weeks of depleted diet consumption. On the other hand, liver retinol concentrations were $67 \%$ lower than in control animals (5.9 (SEM 1.8) v. 18.0 (SEM 2.3) nmoles/g liver).

\section{Effect of vitamin A deficiency on serum retinol and triiodothyronine}

Serum retinol concentration was significantly diminished by VAD $(0.31$ (SEM 0.03) v. 1.31 (SEM 0.10) $\mu \mathrm{mol} / 1$ in depleted and control rats, respectively). In contrast, $\mathrm{T}_{3}$ serum levels were unchanged in deficient animals compared with controls (1.06 (SEM 0.11) v. 1.01 (SEM $0.07) \mathrm{nmol} / \mathrm{l}$ in depleted and control rats, respectively). Data are for the measures performed on six animals.

Effect of vitamin A deficiency on nuclear receptors and target genes

The results are summarized in Tables 3 and 4 .

Effect on all-trans-retinoic acid nuclear receptor, retinoid $X$ receptor and tissue transglutaminase

In accordance with our previous results obtained in the brain of vitamin A-depleted mice (Enderlin et al. 2000), the expression of RAR $\beta$, RXR $\beta / \gamma$ and the activity of tTG decreased in the rat brain after 10 weeks of the depleted diet. Indeed, in these rats, the amounts of $\mathrm{RAR} \beta$ and $\mathrm{RXR} \beta / \gamma$ mRNA were lower $(-36$ and $-24 \%$, respectively) than in the brain of control rats (Table 3). Simultaneously, a significantly reduced tTG activity $(-35 \%)$ was observed (234 (SEM 20) v. 362

Table 3. Influence of vitamin A-deficient diet on the abundance of retinoic acid $(\operatorname{RAR} \beta)$ and triiodothyronine $(T R \alpha / \beta)$ nuclear receptor $(\mathrm{RXR} \beta / \gamma) \mathrm{mRNA}$ in rat brain $\dagger$

(Mean values and standard errors of the mean for six animals)

\begin{tabular}{|c|c|c|c|c|c|c|}
\hline & \multicolumn{6}{|c|}{ mRNA (\% GAPDH) } \\
\hline & \multicolumn{2}{|c|}{$\mathrm{RAR} \beta$} & \multicolumn{2}{|c|}{$\mathrm{RXR} \beta / \gamma$} & \multicolumn{2}{|c|}{$\mathrm{TR} \alpha / \beta$} \\
\hline & Mean & SEM & Mean & SEM & Mean & SEM \\
\hline Controls & 0.150 & 0.010 & 0.920 & 0.046 & $7 \cdot 96$ & 0.48 \\
\hline Depleted & $0.096^{*}$ & 0.009 & $0.700^{*}$ & 0.035 & $5 \cdot 55^{\star}$ & 0.36 \\
\hline
\end{tabular}

GAPDH, glyceraldehyde 3-phosphate dehydrogenase; RAR, retinoic acid receptor; $R X R$, retinoid $X$ receptor; $T R$, triiodothyronine nuclear receptor.

* Mean values were significantly different from those of the control animals $(P<0.05)$. (ANOVA followed by Student's $t$ test).

†For details of diet and procedures, see Table 1 and pp. 192-193. 
Table 4. Influence of vitamin A deficiency on the abundance of neurogranin $\mathrm{mRNA}$ and protein in rat brain (Mean values and standard errors of the mean for six animals)

\begin{tabular}{|c|c|c|c|c|}
\hline & \multicolumn{4}{|c|}{ Neurogranin } \\
\hline & \multicolumn{2}{|c|}{$\begin{array}{c}\text { mRNA } \\
(\% \text { GAPDH) }\end{array}$} & \multicolumn{2}{|c|}{$\begin{array}{c}\text { Protein } \\
\text { (\% controls) }\end{array}$} \\
\hline & Mean & SEM & Mean & SEM \\
\hline Controls & 102 & 6 & 100 & 5 \\
\hline Depleted & $74^{*}$ & 4 & $63^{*}$ & 3 \\
\hline
\end{tabular}

GAPDH, glyceraldehyde 3-phosphate dehydrogenase.

* Mean values were significantly different from those of the control animals $(P<0.05)$ (ANOVA followed by Student's $t$ test). †For details of diet and procedures, see, Table 1 and pp. 192-193.

(SEM 20) fmol/h per mg protein in depleted and control rats, respectively).

\section{Effect on triiodothyronine nuclear receptor}

Together with a reduced expression of $\operatorname{RAR} \beta$ and $\operatorname{RXR} \beta / \gamma$, VAD led to a decrease in $\mathrm{TR} \alpha / \beta$ mRNA of about $30 \%$ (Table 3 ). This decrease had previously been shown only in the liver of depleted rats (Pailler-Rodde et al. 1991).

\section{Effect on neurogranin}

The VAD was accompanied by an alteration in the expression of $\mathrm{RC} 3$, a $\mathrm{T}_{3}$ and $\mathrm{RA}$ target gene. Indeed, in depleted rats, a reduced expression of mRNA and protein $(-27$ and $-37 \%$, respectively) was observed (Table 4$)$. In contrast, immunoblots of depleted and control homogenized brains with $\beta$-actin antibody (detected as a single band migrating at $42 \mathrm{kDa}$ ) revealed no differences of intensity between these two groups. The results concerning RC3 were in agreement with previous results showing a similar decrease in depleted mice (Etchamendy et al. 2000).

Effect of retinoic acid and/or triiodothyronine administration on nuclear receptors and target genes

The results are summarized in Figs. 2, 3 and 4.

\section{Effect on retinoic acid receptor, retinoid $X$ receptor and tissue-type transglutaminase}

Following RA and/or $\mathrm{T}_{3}$ administration in vitamin Adepleted rats, increased amounts of RAR $\beta(+34 \%$ with $\mathrm{RA},+35 \%$ with $\mathrm{T}_{3}$ and $+57 \%$ with $\mathrm{RA}$ and $\left.\mathrm{T}_{3}\right)$ and $\mathrm{RXR} \beta / \gamma\left(+31 \%\right.$ with $\mathrm{RA},+24 \%$ with $\mathrm{T}_{3}$ and $+30 \%$ with RA and $\mathrm{T}_{3}$ ) mRNA were observed (Fig. 2). This also led to an increase in tTG activity of about $85 \%$ with RA, $50 \%$ with $\mathrm{T}_{3}$ and $90 \%$ with RA and $\mathrm{T}_{3}$ (Fig. 3 ).

\section{Effect on triiodothyronine nuclear receptor}

In vitamin A-deficient rats, the abundance of $T R \alpha / \beta$ mRNA was unchanged after administration of RA. On the other hand, an increase in mRNA level after administration

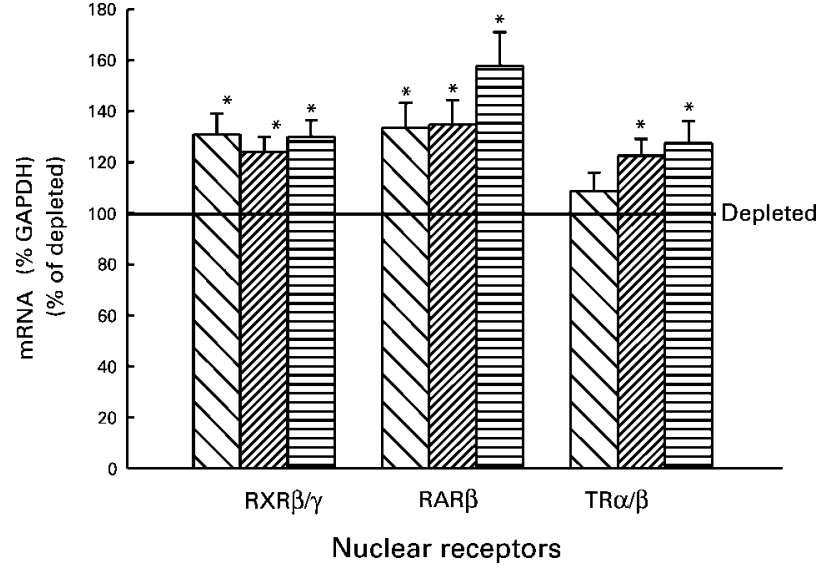

Fig. 2. Effect of retinoic acid (RA) and/or triiodothyronine $\left(T_{3}\right)$ administration $(150 \mu \mathrm{g} / \mathrm{kg}$ body weight per $\mathrm{d}$ for $4 \mathrm{~d}$ ) on retinoid $X$ receptor $(\mathrm{RXR} \beta / \gamma)$, retinoic acid receptor $(\mathrm{RAR} \beta)$ and triiodothyronine receptor $(\operatorname{TR} \alpha \beta)$ mRNA levels in the brain of vitamin Adeficient rats. Data represent the mean values of the measures performed on six animals with the standard errors of the mean represented by vertical bars. *Mean value was significantly different from that of depleted animals $(P<0.05)$. Data were analysed using ANOVA followed by Student's $t$ test. $(\mathbb{\nabla})$, depleted +RA; $(\mathbb{Q})$, depleted $+\mathrm{T}_{3}$; (目) depleted + RA + $\mathrm{T}_{3} ; \mathrm{GAPDH}$, glyceraldehyde 3-phosphate dehydrogenase.

of $\mathrm{T}_{3}$ with or without RA of about 27 and $23 \%$, respectively, was observed (Fig. 2).

\section{Effect on neurogranin}

Concerning RC3, the administration of $\mathrm{T}_{3}$ with or without RA increased RC3 mRNA $(+35$ and $+32 \%$, respectively) and protein $(+131$ and $+38 \%$, respectively) abundance, whereas no change was observed after administration of RA (Fig. 4). Moreover, immunoblots revealed no treatment-related differences between groups concerning the intensity of $\beta$-actin.

\section{Discussion}

Our data showed that rats fed a vitamin A-deprived diet exhibited a hypo-activity of the retinoid signalling pathway, characterized by a decreased amount of RAR $\beta$ and $\mathrm{RXR} \beta / \gamma$ mRNA and tTG activity in the brain with respect to control rats. Comparable results have already been obtained in the rat brain (Verma et al. 1992; Yagamata et al. 1993), and recently in vitamin A-deficient mouse brain (Enderlin et al. 2000). The present study also revealed that $\mathrm{VAD}$ impaired the cellular action of $\mathrm{T}_{3}$ with consequences in the brain. Indeed, it provides the first evidence for a decreased expression of the TR mRNA in vitamin A-depleted rat brain, and, as previously observed in mice (Etchamendy et al. 2000), a hypoexpression of the amount of mRNA as well as of proteins of RC3 which is a $\mathrm{T}_{3}$ target gene. These results were coherent with data obtained in vitamin A-deficient rat liver, which have revealed a decreased transport of $T_{3}$ into target cells (Higueret \& Garcin, 1984; Pailler-Rodde et al. 1991). Besides, in the present work, the cellular activity 


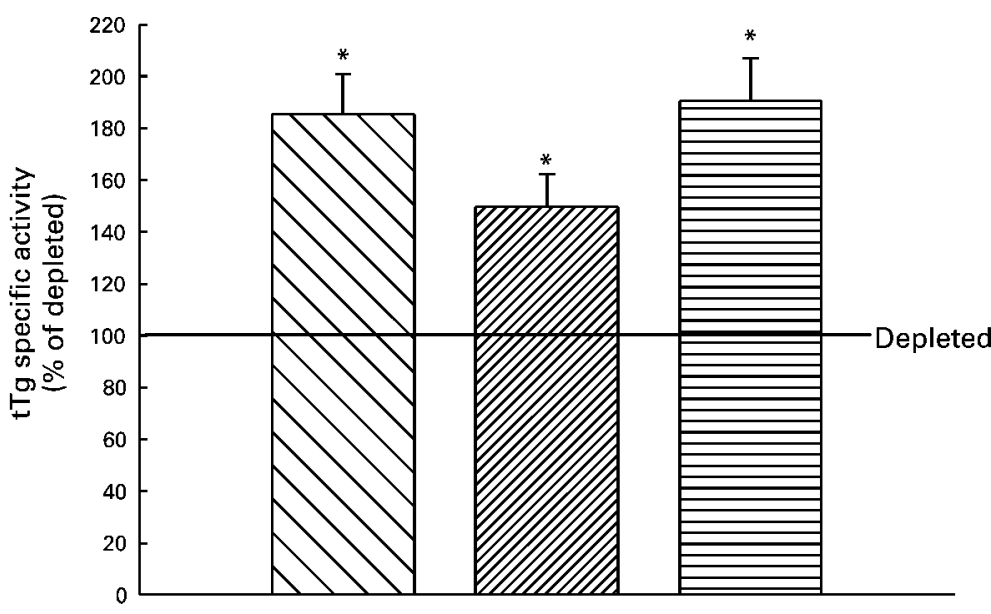

Fig. 3. Effect of retinoic acid (RA) and/or triiodothyronine $\left(T_{3}\right)$ administration $(150 \mu \mathrm{g} / \mathrm{kg}$ body weight per $\mathrm{d}$ for $4 \mathrm{~d})$ on tissue-type transglutaminase activity in the brain of vitamin A-deficient rats. Data represent the mean values of the measures performed on six animals, with the standard errors of the mean represented by vertical bars. *Mean value was significantly different from that of depleted animals $(P<0 \cdot 05)$. Data

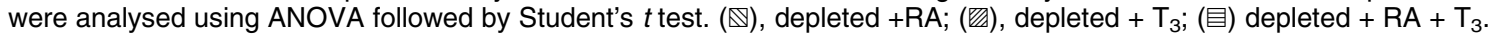

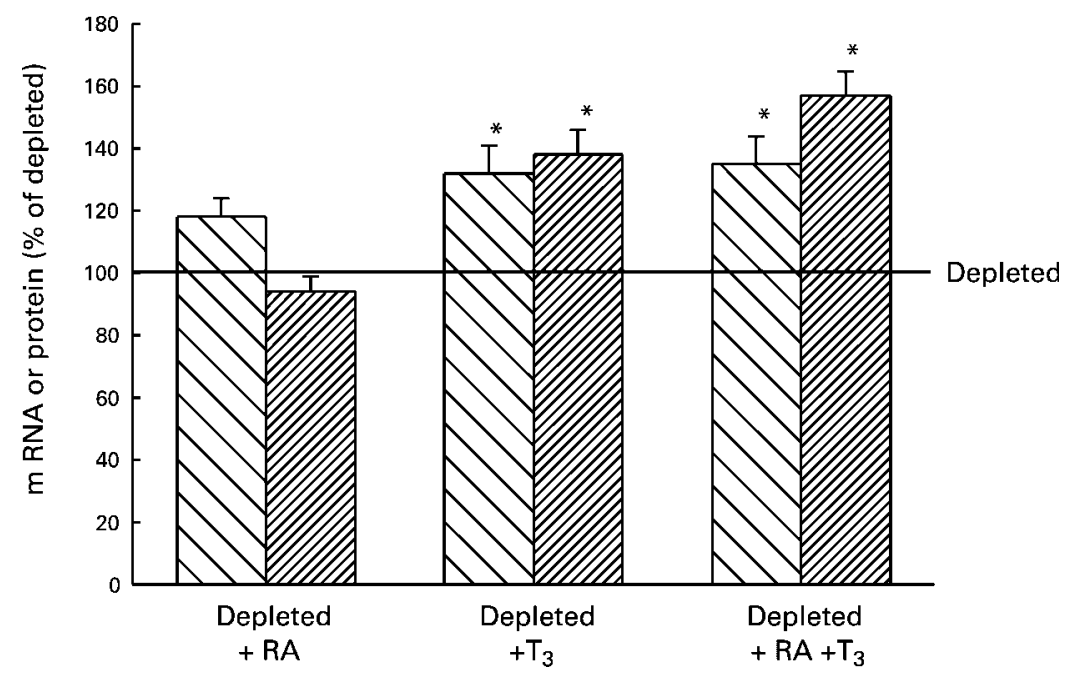

Fig. 4. Effect of retinoic acid (RA) and/or triiodothyronine $\left(T_{3}\right)$ administration $(150 \mu \mathrm{g} / \mathrm{kg}$ body weight per $\mathrm{d}$ for $4 \mathrm{~d})$ on neurogranin mRNA ( $\left.\mathbb{Q}\right)$ and protein (ש्Z) levels in the brain of vitamin A-deficient rats. Data represent the mean values of the measures performed on six animals, with the standard errors of the mean represented by vertical bars. ${ }^{*}$ Mean value was significantly different from that of depleted animals $(P<0.05)$. Data were analysed using ANOVA followed by Student's $t$ test.

of malic enzyme, which is controlled by $\mathrm{T}_{3}$ in rat liver, kidney and heart (Jeannin et al. 1998) was decreased by about $50 \%$ in vitamin A-deficient rat liver (data not shown) indicating that the cellular action of $\mathrm{T}_{3}$ is decreased in vitamin A-deficient rats. Thus, the decreased amount of TR mRNA observed in depleted rats would be, indeed, the result of a decreased $T_{3}$ cellular bioavailability.

Present data are coherent with several findings which revive the concept of permanent interactions between thyroid hormone and vitamin A metabolisms. For example: (i) epidemiological data suggest that low serum retinol levels favour the appearance of goitrous disease in a manner comparable to I deprivation (Ingenbleek \& De Visscher, 1979); (ii) the enhancement of retinoid pathways seems to depend on the secretory rate of transthyretin (which conveys thyroid hormone) (Ingenbleek \& Bernstein, 1999). Moreover, previous study has revealed that the modulation of the binding properties of RAR as well as of TR by RA was dependent on thyroid status (Pallet et al. 1994).

As observed in vitamin A-depleted mice, the reactivation by RA treatment of its own signalling (auto-regulation) was demonstrated in depleted rats by a normalization of the expression of brain receptor (RAR $\beta$ and $\mathrm{RXR} \beta / \gamma$ ) and tTG activity. Nevertheless, whereas in rats that are not vitamin A-deficient, RA is able to up regulate RC3 (Enderlin et al. 1997; Etchamendy et al. 2001), in vitamin A-deficient rats the administration of RA failed to normalize the expression of RC3 as well as of TR. Thus, to evaluate the involvement of $\mathrm{T}_{3}$ on RA signalling in depleted rats, RA administration was compared with $\mathrm{T}_{3}$ administration or $\mathrm{T}_{3}$ and RA co-administration. Interestingly, the results showed that the administration of $\mathrm{T}_{3}$ alone is able to reverse its own brain hypo-signalling 
(auto-regulation) simultaneously with that of RA (heteroregulation) and the hypo-expression of RC3 mRNA and proteins. Moreover, our experiments revealed a synergetic effect of RA and $\mathrm{T}_{3}$, first on the mRNA expression of RAR which increased by about $35 \%$ and $57 \%$ after either $\mathrm{T}_{3}$ or $\mathrm{T}_{3}+\mathrm{RA}$ administration, respectively, and second, on the protein expression of RC3. Therefore, the regulation of RC3 by RA in VAD is dependent on $T_{3}$ levels in spite of a RA-responsive element in the RC3 gene promoter.

Our results indicate that one of the consequences of $\mathrm{VAD}$ is a dysfunction in the thyroid signalling pathway in the brain. This seems of crucial importance since the down regulation of $\mathrm{RC} 3$ observed in the depleted rats was corrected only by $\mathrm{T}_{3}$. It seems that in vitamin $\mathrm{A}$ deficient rats, hypo-activity of $\mathrm{T}_{3}$ signalling becomes a limiting factor, which impairs RA from exerting its modulator effect. In comparison with previous works in depleted mice, showing that a sufficient level of vitamin A was required for the maintenance of mature brain function, the novel finding here is that vitamin A seems effective through the preservation of the integrity of the $T_{3}$ signalling.

Vitamin A deficiency seems to be associated with integrative and probably adaptive processes, suggesting that many physiological functions, at least vitamin $\mathrm{A}$ and $\mathrm{T}_{3}$ signalling, are mobilized and become stabilized at new levels far from homeostatic equilibrium. In our opinion, this situation corresponds to the allostatic state described by Sterling \& Eyer (1988) where the organism resets the parameters of its physiological systems at a new set point, and matches them appropriately to the chronic lack of vitamin A. If the lack continued, the allostatic maladaptation would lead to breakdown (neurobiological disorders) and illness.

More generally our results suggest that vitamin Adepleted animals develop signs of cellular hypothyroidism, since rats exhibit thyroid disorders characterized by alterations of the brain $\mathrm{T}_{3}$ signalling and related target-gene hypo-expression which is reversed only by $\mathrm{T}_{3}$ administration. Given the VAD-related neurological alterations, further investigation would provide insights into VAD management, a public health problem in many areas of the world, according to its severity.

\section{Acknowledgements}

This research was supported by the Institut National de la Recherche Agronomique (INRA) and by the Conseil Régional d'Aquitaine.

\section{References}

Alfos S, Higueret P, Pallet V, Higueret D, Garcin H \& Jaffard R (1996) Chronic ethanol consumption increases the amount of mRNA for retinoic acid and triiodothyronine receptors in mouse brain. Neurosci Lett 206, 73-76.

Audouin-Chevallier I, Higueret P, Pallet V, Higueret D \& Garcin H (1993) Dietary vitamin A modulates the properties pf retinoic acid and glucocorticoid receptors in rat liver. Am Instit Nutr 123, 1195-1202.
Bradford M (1976) A rapid and sensitive method for a quantitation of microgram quantities of protein utilizing the principle of protein-dye binding. Anal Biochem 72, 248-254.

Chambon P (1996) A decade of molecular biology of retinoic acid receptors. FASEB $J \mathbf{1 0}, 940-954$.

Chiang MY, Misner D \& Kempermann G, et al. (1998) An essential role for retinoid receptors RAR $\beta$ and RXR $\gamma$ in long-term potentiation and depression. Neuron 21, 1353-1361.

Chin WW \& Yen PM (1997) Molecular mechanisms of nuclear thyroid hormone action. In Contemporary Endocrinology: Diseases of the Thyroid, pp. 1-10 [LE Braverman Humana, editor]. Totowa, NJ: Press Inc..

Chiocca EA, Davies PJ \& Stein JP (1989) Regulation of tissue transglutaminase gene expression as a molecular model for retinoid effects on proliferation and differentiation. $J$ Cell Biochem 39, 293-304.

Chomczynski P \& Sacchi N (1987) Single step method of RNA isolation by acid guanidium thiocyanate-phenol-chloroform extraction. Anal Biochem 162, 156-159.

Cocco S, Diaz G \& Stancampiano R, et al. (2002) Vitamin A deficiency produces spatial learning and memory impairment in rats. Neuroscience 115, 475-482.

Connor MJ \& Sidell N (1997) Retinoic acid synthesis in normal and Alzheimer diseased brain and human neural cells. Mol Chem Neuropathol 30, 239-252.

Enderlin V, Higueret D \& Alfos S, et al. (2000) Vitamin A deficiency decreases the expression of RAR $\beta$ and $\mathrm{RXR} \beta / \gamma$ in adult mouse brain: effect of RA administration. Nutr Neurosci 3, $173-181$.

Enderlin V, Pallet V \& Alfos S, et al. (1997) Age-related decreases in mRNA for brain nuclear receptors and target genes are reversed by retinoic acid treatment. Neurosci Lett 229, $125-129$.

Etchamendy N, Enderlin V, Marighetto A, Pallet V, Higueret P \& Jaffard R (2000) Evidence for a role of vitamin A in higher cognitive functions. Society Neurosci Abstr 26, 1748.

Etchamendy N, Enderlin V \& Marighetto A, et al. (2001) Alleviation of a selective age-related relational memory deficit in mice by pharmacologically induced normalization of brain retinoid signaling. J Neurosci 21, 6423-6429.

Gerendasy DD \& Sutcliffe JG (1997) RC3/neurogranin, a postsynaptic calpacitin for setting the response threshold to calcium influxes. Mol Neurobiol 15, 131-163.

Guadaño-Ferraz A, Escamez MJ, Morte B, Vargiu P \& Bernal J (1997) Transcriptional induction of RC3/neurogranin by thyroid hormone: differential neuronal sensitivity is not correlated with thyroid hormone receptor distribution in the brain. Mol Brain Res 49, 37-44.

Higueret P \& Garcin H (1982) Peripheral metabolism of thyroid hormones in vitamin A-deficient rats. Annals Nutr Metab 26, 191-200.

Higueret P \& Garcin H (1984) Triiodothyronine and vitamin Adeficiency in the rat. J Physiol (Paris) 79, 373-377.

Ingenbleek Y \& Bernstein LH (1999) The nutritionally dependent adaptive dichotomy (NDAD) and stress hypermetabolism. $J$ Clinical Ligand Assay 22, 259-267.

Ingenbleek Y \& De Visscher M (1979) Hormonal and nutritional status: critical conditions for endemic goiter epidemiology? Metabolism 28, 9-19.

Iñiguez MA, Morte B \& Rodriguez-Pena A, et al. (1994) Characterization of the promoter region and flanking sequences of the neuron-specific gene RC3 (neurogranin). Brain Res Mol Brain Res 27, 205-214.

Jeannin E, Robyr D \& Desvergne B (1998) Transcriptional regulatory patterns of the myelin basic protein and malic enzyme genes by the thyroid hormone receptors alpha1 and beta1. J Biol Chem 273, 24239-24248. 
Kastner P, Mark M \& Chambon P (1995) Nonsteroid nuclear receptors: what are genetic studies telling us about their role in real life? Cell 83, 859-869.

Környei Z, Toth B, Tretter L \& Madarasz E (1999) Effects of retinoic acid on rat forebrain cells derived from embryonic and perinatal rats. Neurochem Int 33, 541-549.

Krezel W, Kastner P \& Chambon P (1999) Differential expression of retinoid receptors in the adult mouse central nervous system. Neuroscience 89, 1291-1300.

Leclercq M \& Bourgeay-Causse M (1981) Une méthode simple, fiable rapide: dosage simultané du rétinol et du tocophérol sérique par chromatographie liquide haute performance (A simple, reliable fast method: simultaneous proportioning of retinol and serum tocopherol by high performance liquid chromatography). Revue Institut Pasteur Lyon 14, 475-496.

McCaffery P \& Dräger UC (1994) High levels of a retinoic acid-generating dehydrogenase in the meso-telencephalic dopamine system. Proc Natl Acad Sci USA 91, 7772-7776.

Maden M, Gale E \& Zile M (1998) The role of vitamin A in the development of the central nervous system. J Nutr 128, 471S-475S.

Malik MA, Blusztajn JK \& Greenwood CE (2000) Nutrients as trophic factors in neurons and the central nervous system: Role of retinoic acid. J Nutr Biochem 11, 2-13.

Mangelsdorf DJ, Borgmeyer U \& Heyman RA, et al. (1992) Characterization of three RXR genes that mediate the action of 9-cis retinoic acid. Genes Dev 6, 329-344.

Martinez de Arrieta C, Morte B, Coloma A \& Bernal J (1999) The human RC3 gene homolog, NRGN contains a thyroid hormone-responsive element located in the first intron. Endocrinology 140, 335-343.

Misner DL, Jacobs S \& Shimizu Y, et al. (2001) Vitamin A deprivation results in reversible loss of hippocampal longterm synaptic plasticity. Proc Natl Acad Sci USA 98, 11714-11719.

Morte B, Iñiguez MA, Lorenzo PI \& Bernal J (1997) Thyroid hormone-regulated expression of $\mathrm{RC} 3 /$ neurogranin in the immortalized hypothalamic cell line GT1-7. J Neurochem 69, 902-909.

Murray MB, Zilz ND, McCreary NL, MacDonald MJ \& Towle $\mathrm{HC}$ (1988) Isolation and characterization of rat cDNA clones for two distinct thyroid hormone receptors. J Biol Chem 263, $12770-12777$.

Okamura K, Taurog A \& Distefano JJ (1981) Elevated serum levels of T3 without metabolic effect in nutritionally deficient rats, attributable to reduced cellular uptake of T3. Endocrinology 109, 673-675.

Pailler-Rodde I, Garcin H, Higueret P \& Begueret J (1991) c-erb-A mRNA content and triiodothyronine nuclear receptor binding capacity in rat liver according to vitamin A status. FEBS Lett 289, 33-36.

Pak JH, Huang FL, Li J, et al. (2000) Involvement of neurogranin in the modulation of calcium/calmodulindependent protein kinase II, synaptic plasticity, and spatial learning: a study with knockout mice. Proc Natl Acad Sci USA 97, 11232-11237.

Pallet V, Audouin-Chevallier I, Verret C, Garcin H \& Higueret P (1994) Retinoic acid differentially modulates triiodothyronine and retinoic acid receptors in rat liver according to thyroid status. Eur J Endocrinol 131, 377-384.

Sabath DE, Broome HE \& Prystowsky MB (1990) Glyceraldehyde-3-phosphate dehydrogenase mRNA is a major interleukin 2-induced transcript in a cloned T-helper lymphocyte. Gene $\mathbf{9 1}$, $185-191$.

Savouré N, Nio C, Maudet M \& Nicol M (1996) Liver transglutaminases and vitamin-A deficiency in hairless mice. Ann Nutr Metab 40, 52-60.

Schräder M \& Carlberg C (1994) Thyroid hormone and retinoic acid receptors form heterodimers with retinoid $\mathrm{X}$ receptors on direct repeats, palindromes, and inverted palindromes. DNA Cell Biol 13, 333-341.

Sporn MB, Roberts AB \& Goodman DS (1994) The Retinoids. Biology, Chemistry and Medicine, 2nd ed. New York, NY: Raven Press.

Sterling P \& Eyer J (1988) Allostasis: A new paradigm to explain arousal pathology. In Handbook of Life Stress, Cognition and Health, pp. 629-649 [S Fisher and J Reason, editors]. Chichester, UK: John Wiley.

Verma AK, Shoemaker A, Simsiman R, Denning M \& Zachman $\mathrm{R}$ (1992) Expression of retinoic acid nuclear receptors and tissue transglutaminase is altered in various tissues of rats fed with a vitamin A-deficient diet. J Nutr 122, 2144-2152.

Watson JB, Battenberg EF, Wong KK, Bloom FE \& Sutcliffe J (1990) Subtractive cDNA cloning of RC3, a rodent cortexenriched mRNA encoding a novel 78 residue protein. J Neurosci Res 26, 397-408.

Yagamata T, Momoi T, Kumagai H, Nishikawa T, Yanagisawa M \& Momoi M (1993) Distribution of retinoic acid receptor $\beta$ proteins in rat brain: up-regulation by retinoic acid. Biomed Res 14, 183-190.

Zelent A, Krust A, Petkovich M, Kastner P \& Chambon P (1989) Cloning of murine alpha and beta retinoic acid receptors and a novel receptor gamma predominantly expressed in skin. Nature 339, 714-717.

Zetterström RH, Lindqvist E, Mata de Urquiza A, et al. (1999) Role of retinoids in the CNS: differential expression of retinoid binding proteins and receptors and evidence for presence of retinoic acid. Eur J Neurosci 11, 407-416. 